\title{
Planning Review: Developments and Planning Issues of Land Use Control in Suburban Areas by Local Government's Ordinances in Japan
}

\author{
Toshimitsu MASHIMA ${ }^{1}$ and Mitsuhiko KAWAKAMI ${ }^{2 *}$ \\ 1 Nihonkai Consultant Ltd. \\ 2 School of Environmental Design, Kanazawa University \\ * Corresponding Author, Email: kawakamim@staff.kanazawa-u.ac.jp \\ Received 19 Feberuary, 2013; Accepted 10 January 2014
}

Key words: Suburban Area, Land Use System, Development Permission Ordinance, Voluntary Ordinance

\begin{abstract}
This study aims to clarify how changes in the legal system combined with changing social, economic, and environmental pressures have affected approaches taken for land use control. Our emphasis is on how historical transitions in the legal system, particularly in the use of local government ordinances (Development Permission Ordinances and voluntary ordinances concerning land use management) have contributed to land use control in suburban areas. Our results show that because of the revision of the City Planning Law in 2000, more municipalities are introducing planned land use control in suburban areas. These are local efforts that consider the local situation. However, planned lands use has also been used to relax regulations, thereby promoting traditional growth and expansion trends. This has been especially true in the Kanto region, where development pressure is high. Therefore, it is necessary to design land use control systems that are consistent with the goals of making compact urban areas and a stable society. To do so, it is critical to clarify planning goals through public participation, evaluate the municipality's administrative abilities and applicant responsibilities, identify those developments that are to be regulated, and guide development with flexibility. It is also recommended that financial and technical support should be provided for public participation.
\end{abstract}

\section{INTRODUCTION}

The land use system in Japan is founded upon the zoning (hereafter "Area Division") and Development Permission System that was created under the New City Planning Law enacted in 1968. The system aims to tackle severe urban problems caused by rapid growth of population and industry, urban concentration of population and industry, and urban sprawl in suburban areas. If it is necessary, a City Planning Area is divided by Area Division into an "Urbanization Promotion Area (UPA)," in which urbanization is promoted, and an "Urbanization Control Area (UCA)," in which urbanization and land use activities are controlled through the Development Permission System. By implementing the Area Division and Development Permission System, public facilities have been mainly built in UPAs, environmental standards have been preserved, disasters have been 
prevented, and convenience has been enhanced. In addition, at least in principle, developments in UCAs have been prohibited, and urban sprawl has been controlled.

However, the Development Permission System led by the central government was an institutionalized form of minimum standards applied throughout the country with the result that some municipalities have not been able to adequately control land use activities. In particular, it was not possible to control development that was not subject to the Development Permission System. This included small-scale development and nonbuilding development, such as outdoor parking lots and material yards. Consequently, many municipalities around large cities have experienced high development pressures, leading to urban expansion without sufficient public infrastructure but with financial responsibilities that have become burdensome. Furthermore, many central cities in local regions contain NonArea Divided City Planning Areas and regions other than City Planning Areas. In these areas, land use control is rarely implemented and various problems, including urban sprawl, have arisen.

To deal with these problems, some leading local governments began to control land use activities through voluntary ordinances and planning guidance (development rules that local government established for managing land development). In addition, with the recent trend of decentralization, the relationship between the national government and regional public agencies was re-evaluated fundamentally; this was formalized in 1999 by the "Law Concerning Provision of Related Laws for Promoting Decentralization (hereafter, the 'Omnibus Law of Municipal Sovereign Reform')." Due to the elimination of assigned functions by the central government and expansion of local government ordinance enactment rights, as well as transfers of various authorities, traditional centralized urban planning reached a turning point; thereafter, urban planning was to be mainly handled by local governments.

Along with such institutional changes, Japan entered an era of decreasing population and an aging society. The country must now shift from a traditional centralized "growth/expansion society" to a decentralized and sustainable "mature society." However, to reform the land use system, it is necessary to evaluate not only the existing uniform system but also a detailed land use control system that pertains to individual municipal situations. Such evaluations should consider gaps between the three major metropolitan areas and other local urban areas as well as differences within its own region or city. Particularly among suburban areas (mainly to UCA, a non-use-specified area in the non-Area Divided City Planning Areas and an area outside the City Planning Areas), levels of development control significantly differ, depending on the prevailing form of land use systems. Thus, in addition to common development regulations that are intended to prevent traditional sprawl, it is important to have a perspective that guides development to a regional hub and existing settlements so as to maintain and revitalize such areas.

Therefore, this study focuses on suburban areas and aims to evaluate transitions in land use systems as well as the positions/roles of local government ordinances (it refers to a combination of a delegation ordinance in accordance with the City Planning Law and the Building Standards Law, and a voluntary ordinance which a local government uniquely enacts in accordance with Section 1, Article 14 of the Local Autonomy Act). We also seek to clarify the effects and planning issues by analyzing those local government ordinances that control land use activities in suburban areas. 
Existing studies that compare the land use system and its operation specified in metropolitan area of foreign countries with our country, such as Germany, England, the Netherlands, point out necessities for securing of realization of the master plan, and the mutual adjustment between different levels of governmental bodies(Ubaura,et al.,2008; Rai and Marushige, 2006).

In addition, the existing studies that investigate Japanese local government ordinances for land use control are as follows, researches that analyses designation status and actual conditions of Development Permission Ordinances within delegation ordinances (Sections 11 and 12, Article 34 of the City Planning Law) and Special Use Restricted Areas (Tsukamoto and Wada, 2005; Ohkawa, et al, 2009; Asano and Fujiwara, 2010; Kakiuchi, et al, 2010; Fujii,et al, 2009), and researches that analyzes the content, mechanisms, and actual conditions of voluntary ordinances(Uchiumi and Kobayashi,1998; Akita, et al, 2001; Akita, et al, 2003; Nozawa and Hori, 2008; Tadokoro and Kato,2011). Although there are many existing studies that analyze the content of designation of individual ordinances and their actual conditions, and evaluate operational issues and effects, few of them clarify the roles, effects, and issues of delegation and voluntary ordinances in land use systems from the perspective of local government ordinances. Therefore, this study should help clarify the advantages and limitations that can arise when local government ordinances are used to develop land use systems in a future decentralized society.

\section{STUDY METHODS}

We start by using the existing literature to study (a) the evolution of legal systems as they relate to suburban land use and (b) the positions adopted and roles played by local government ordinances.

To clarify designation status and actual conditions of suburban land use control by local government ordinances, this study focuses on Development Permission Ordinances on the basis of the revised City Planning Law under the enactment of the Omnibus Law of Decentralization. We also study voluntary ordinances for land use management(Uchiumi and Kobayashi,1998); these have been expanded as the ordinance enactment right. Regarding Development Permission Ordinances, this study analyzes the development permission situation after the system was established from 2001 to 2009; we compare three major metropolitan areas and other areas on the basis of Survey on Development Implementation Status (research at the end of March by Development, Planning and Research Office, City Planning Division, City and Regional Development Bureau, Ministry of Land, Infrastructure, Transport and Tourism). Regarding voluntary ordinances for land use management, this study collects examples from websites (using

"Ordinance Web" ) of local governments to understand the designation status; this study also analyzes actual conditions on the basis of questionnaires $^{7)}$ completed by selected municipalities. As a result 77 questionnaires were distributed and 76 were collected, which makes collection rate $99 \%$. Using these processes, the study discusses the effectiveness and planning issues of local government ordinances. 


\section{TRANSITION OF LAND USE SYSTEMS IN SUBURBAN AREAS}

Table 1 documents transitions in land use systems in suburban areas. Regarding the land use systems of Japan, the National Land Utilization Law was enacted in 1974 to promote comprehensive and well-planned national land use and to systemize individual laws, such as the existing City Planning Law and the Law on Establishment of Agricultural Promotion Regions. However, in reality, there are issues that are controlled by individual Laws; an example of such an issue is the specific management of those regions that are categorized as Urban Area, Agricultural Area, Forest Area, Natural Park Area, and Natural Preservation Area. Consequently, the original goal of comprehensive coordination is not working.

Table 1 Transition of Land Use Systems in Suburban Areas(Tsukamoto and Wada, 2005; Ohkawa, et al, 2009; Asano and Fujiwara, 2010; Kakiuchi, et al, 2010; Fujii,et al, 2009)

\begin{tabular}{|c|c|c|}
\hline Period & Laws Related to Urban Planning & $\begin{array}{c}\text { Laws Related to Agricultural Land and } \\
\text { Decentralization }\end{array}$ \\
\hline $60^{\prime}$ & $\begin{array}{l}\text { (New) City Planning Law }<68> \\
\cdot \text { Broadening of City Planning Area, delegation of urban planning discretion, } \\
\text { etc. } \\
\cdot \text { Zoning of UPA and UCA, Development Permission Sy stem }\end{array}$ & $\begin{array}{l}\square \text { Law on Establishment of Agricultural Promotion } \\
\text { Regions }\langle 69>\end{array}$ \\
\hline $70^{\prime}$ & 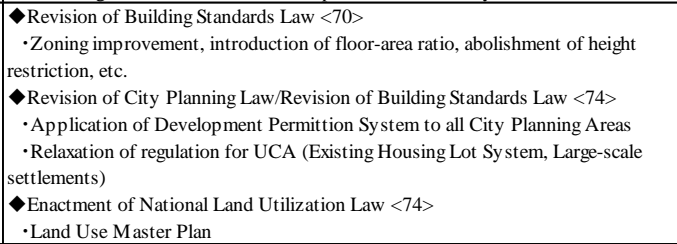 & $\square$ Revision of Agricultural Land Law $<70>$ \\
\hline $80^{\prime}$ & $\begin{array}{l}\text { Revision of City Planning Law/ Building Standards Law <80> } \\
\cdot \text { Establishment of District Planning (application to UPA) } \\
\text { Revision of City Planning Law < } 83> \\
\cdot \text { Reduction of planned large-scale development areas in UCA }\end{array}$ & $\begin{array}{l}\square \text { Revision of Agricultural Land Law }<84> \\
\square \text { Suburban Community Area Improvement Law } \\
<87> \\
\triangle \text { Enactment of Law for Arranging Integrated } \\
\text { Recreation Areas }\langle 87>\end{array}$ \\
\hline $90^{\prime}$ & $\begin{array}{l}\text { Revision of City Planning Law }\langle 92> \\
\cdot \text { Compulsory preparation of municipal master plans, zoning improvement } \\
\text { - Application of District Plan in UCA, etc. } \\
\text { Revision of Building Standards Law <92> } \\
\cdot \text { Minimum lot size for housing (Low-rise residential areas) } \\
\cdot \text { Revision of land use regulations in UCA }\end{array}$ & $\begin{array}{l}\diamond \text { Administrative Procedure Law }\langle 93\rangle \\
\diamond \text { Revision of Local Autonomy Law }\langle 94> \\
\diamond \text { Law for Promotion of Decentralization }\langle 95> \\
\diamond \text { Omnibus Law of Decentralization }\langle 99>\end{array}$ \\
\hline $\begin{array}{l}00^{\prime} \\
\text { and } \\
\text { after }\end{array}$ & $\begin{array}{l}\text { Revision of City Planning Law }\langle 00\rangle \\
\cdot \text { Introduction of Master Plan System for City Planning Area, optional system of } \\
\text { Area Division } \\
\text { - Introduction of Quasi-City Planning Area and Specific usage limitation area } \\
\text { - Application of Development Permission Ordinances in UCA, etc. } \\
- \text { Revision of City Planning Law }<06> \\
\text { - Restriction of site location of large-scale customer facilities, application of } \\
\text { Development Permission for public facilities } \\
\text { - Abolition of large-scale Development Permission criteria in UCA, etc. } \\
- \text { Revision of City Planning Law }<11> \\
\text { - Restict obligations and specifications by the Central Government, and delegate } \\
\text { authorities to municipalities }\end{array}$ & $\begin{array}{l}\square \text { Revision of Agricultural Land Law }<09> \\
\diamond \text { Omnibus Law of Municipal Sovereign Reform } \\
<11>\end{array}$ \\
\hline
\end{tabular}

Suburban areas are mainly categorized as Urban Areas, Agricultural Areas, or Forest Areas, although some areas have overlapping designations. A district designated as an Urban Area is automatically a City Planning Area, and urban land use activities can be controlled under the City Planning Law. However, if a district is only designated as an Agricultural Area or a Forest Area, regulations controlling urban land use are very limited and disorderly developments tend to occur. Furthermore, land use control under the City Planning Law focuses on Area Division and the Development Permission Systems, as described in Section 1. However, since these systems presume metropolitan cities and their surroundings or local major cities, if an adjacent city falls within an area having lax regulations, such as a non-Area Divided Area or a non-City Planning Area, development tends to 
be uneven; this can become a serious issue, especially in local cities. Additionally, since the Law only targets development that includes building activities, outdoor parking lots and material yards that do not accompany building construction are excluded; this can lead to deterioration of rural areas. In light of these problems, some easing measures were introduced to reflect local characteristics, such as the application of the District Planning System (it can be used to regulate in detail building activities and neighboring public facilities such as access roads in a specified area) and the flexible operation of the Development Permission System (Such as the relaxation of development requirements of branch family housing (1982), flexible operation of Reviewing Board of Development (1985), the relaxation of Development Permission System within governor designated areas (1986), etc.) in UCA. However, in principle, uniform and centralized land use systems were implemented that follow trends toward growth and expansion.

As the Omnibus Decentralization Act came into force in 1999, the decentralization movement accelerated. Administrative functions imposed upon local governments by the central government were eliminated, various authorities were transferred to regions, and the ordinance enactment rights of local governments were expanded. Urban planning was placed at the center of decentralization reforms, and in the legal reform of 2000, Area Division was shifted to an optional system, the Quasi-City Planning Area was introduced, the Development Permission Ordinance began to be applied, and the Specific Usage Limitation Area (it can be designated in the area with no designation of Land Use Zones outside UCA and control building activities to preserve favorable living environment and avoid excessive development compared the existing public facilities) was established for land use control in suburban areas. Such changes prompted a big shift that included significantly increased municipal discretion and enabled specific system operations that recognize regional characteristics through local government ordinances. Furthermore, with enforcement of the Omnibus Law of Municipal Sovereign Reform, the legal reform in 2011 accelerated the transfer of authority to municipalities.

In this way, in response to the trend in rapid growth and expansion, the centralized land use regulations with uniform and even minimum criteria played a role in controlling sprawl and in building public facilities. Nevertheless, such regulations have also contributed to various issues, such as those accompanying the increasing age of the contemporary population. These issues require a flexible land use system that considers local situations. The positions, roles, and actual conditions of local government ordinances that have emerged from the recent decentralization are evaluated in the following sections.

\section{ENACTMENT BACKGROUND AND ACTUAL CONDITIONS OF DELEGATION ORDINANCES}

\subsection{Enactment Background and Roles of Delegation Ordinances}

Table 2 shows the delegation provisions in laws related to urban planning. Before the revision of the City Planning Law in accordance with 
the Omnibus Decentralization Law (2000), authorities of local governments were limited to such activities as holding hearings for District Planning proposals and operating the City Planning Committee and the Reviewing Board of Development. Local governments did not have powers for specifying restrictions on urban planning. However, after the revision, the discretion of local governments was expanded so that local government ordinances could set specific criteria on the basis of the City Planning Law. Especially in suburban areas, Development Permission Ordinances (by Sections 11 and 12, Article 34 of the City Planning Law) can ordain measures that grant permission for development in UCAs. Moreover, Specific Usage Limitation Areas were established for land use control in non-Area Divided Areas; this allows local governments to define target districts and allocate permitted building usage. In this way, laws define the content to be stipulated, while each local government is able to define specific contents and to design a system that corresponds to the regional situation.

Table 2. List of Delegation Provisions Related to City Planning

\begin{tabular}{|c|c|c|c|}
\hline Basic Law & Relevant Law & Contents of Restriction & Ordinance Enactment \\
\hline \multicolumn{4}{|l|}{ A City Planning Law } \\
\hline \multicolumn{2}{|l|}{ Article 16, Section 3} & $\begin{array}{l}\text { Oerating of Pulic Hearing for proposals for District Planning, } \\
\text { etc. }\end{array}$ & municipality \\
\hline \multicolumn{2}{|l|}{ Article 33 , Section 3} & $\begin{array}{l}\text { Relaxation and tightening of technical items of Development } \\
\text { Permission }\end{array}$ & municipality \\
\hline \multicolumn{2}{|l|}{ Article 33, Section 4} & Minimum lot area of a building in development districts & municipality \\
\hline \multicolumn{2}{|l|}{ Article 33, Section 5} & $\begin{array}{l}\text { Application of restrictions of developments defined in a } \\
\text { Landscape Plan }\end{array}$ & $\begin{array}{l}\text { Landscape } \\
\text { Administrative Body }\end{array}$ \\
\hline \multicolumn{2}{|l|}{ Article 34, Section 1-11 } & Relaxation of developments in UCA (1) & $\begin{array}{l}\text { prefecture, designated } \\
\text { citiy, etc. }\end{array}$ \\
\hline \multicolumn{2}{|l|}{ Article 34, Section 1-12 } & Relaxation of developments in UCA (2) & $\begin{array}{l}\text { prefecture, designated } \\
\text { citiy, etc. }\end{array}$ \\
\hline \multicolumn{2}{|l|}{ Article 58} & Regulations on buildings in Scenic Area & prefecture, municipality \\
\hline \multicolumn{2}{|l|}{ Article 75 , Section 2} & Collection of appointee fees & municipality \\
\hline \multicolumn{2}{|l|}{ Article 77} & Operation of Prefectural City Planning Council & prefecture \\
\hline \multicolumn{2}{|l|}{ Article 77 , Section 2} & Operation of municipality City Planning Council & municipality \\
\hline \multicolumn{2}{|l|}{ Article 78 , Section 8} & Operation of Reviewing Board of Development & prefecture \\
\hline $\begin{array}{l}\text { B Law of Zoning } \\
\text { and District } \\
\end{array}$ & $\begin{array}{c}\text { Building } \\
\text { Standard Law }\end{array}$ & & \\
\hline $\begin{array}{l}\text { Special Land Use } \\
\text { Districts }\end{array}$ & Article 49 & Restriction of land uses of Special Land Use Districts & municipality \\
\hline \begin{tabular}{|l|} 
Specific Usage \\
Limitation Area \\
\end{tabular} & Article 49-2 & Restrictions of land uses in areas without land use zoningn & municipality \\
\hline Land Use Zone & Article 50 & Restrictions of building structure in Land Use Zoning & municipality \\
\hline Aesthetic area & Article 68 & $\begin{array}{l}\text { Restrictions necessary for preserving aesthetic in Aesthetic } \\
\text { Area }\end{array}$ & municipality \\
\hline Preservation District & Article 85-2 & Relaxation of Building Standard Law in Preservation District & municipality \\
\hline
\end{tabular}

\subsection{Actual Conditions of Land Use Control by Delegation Ordinances}

Among delegation ordinances that control suburban land use, this section studies the actual conditions of Development Permission Ordinances for UCAs. Figure 1 shows permitted developments after the legal reform from 2001 to 2009. First, the annual number of permitted developments was approximately $20,000-25,000$, and the annual total area was 5,000-8,000 ha (An applicable development for permission is more than $1,000 \mathrm{~m}^{2}$ in UPA, all developments in UCA and development more than $3,000 \mathrm{~m}^{2}$ in non-Area 
Divided Area). Regarding development permissions in UCAs, the average permit percentage over the same period was $53 \%$ in all developments and $29 \%$ in all developed land area, showing increasing trends in both number and area.

Since development permissions in UCAs are granted on the basis of location criteria defined in Article 34, the results (Figure 2) show that most developments were those defined in Section 14, which were examined by the Reviewing Board of Development ( $81 \%$ of all development numbers and $66 \%$ of all developed areas) in 2001, just after the legal reform. Thereafter, development permissions by the Development Permission Ordinances by Sections 11 and 12 gradually increased, and the permitted number by Section 11 reached 33\% and those by Section 12 reached 30\% in 2009. This was due to the transfer of relevant development from Section 14 to Section 12 , which covers stylized development and is not necessarily required to be reviewed by a Reviewing Board of Development. In addition, each local government enacted ordinances to utilize Section 11 as an alternative measure replacing the former Existing Housing Lot System. Existing Housing Lot System was established so as to protect the property rights of inhabitants in UCA. Anyone who has an Existing Housing Lot can develop a land lot without Development Permission, where it was confirmed to have already become the residential land in UCA when it was defined as in UCA. Furthermore, large-scale developments that exceed 10 ha and are permitted by Section 10 (District Planning) gradually increased in recent years, although their numbers remain relatively small.
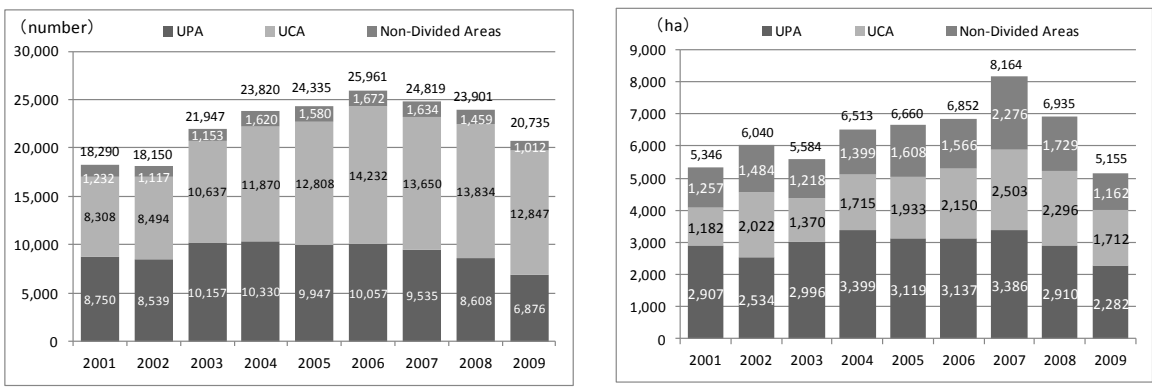

Figure 1. Permitted Development in Each District

(Left: Number of Developments, Right: Area)
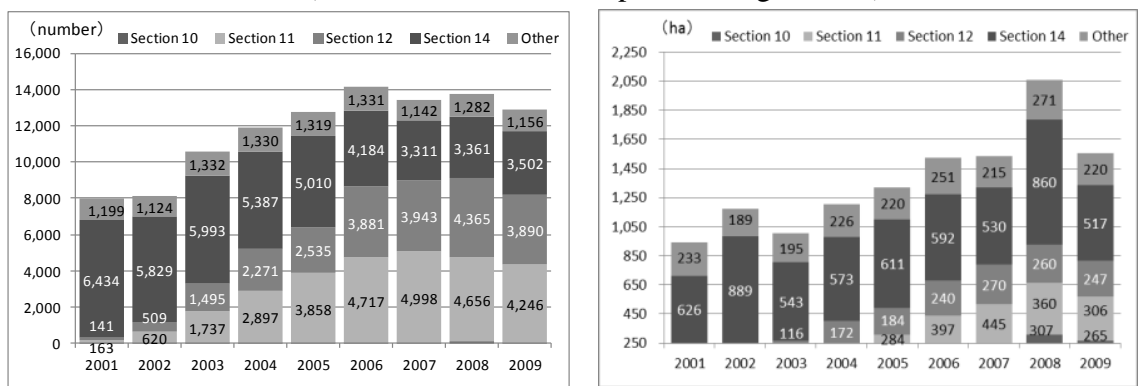

Figure 2. Permitted Development by Article 34 in UCA

(Left: Number of Developments, Right: Area)

The permitted number by Development Permission Ordinances in urban areas (Figure 3) indicates that permits were mostly given (approximately 60\%) in Metropolitan areas. Compared to other prefectures, the number is particularly high in Saitama Prefecture and its designated cities, accounting for approximately $40 \%$. Outside the three metropolitan urban areas, Ibaraki Prefecture and Tochigi Prefecture show large numbers of permits and areas, indicating that the ordinances are especially utilized in areas in the Kanto region, which is under high development pressure. In 
Kawagoe City of Saitama Prefecture, the permits by Section 11 were 825 and 85 ha during the same period. Since the development of suburbs significantly increased, agricultural lands and forest areas decreased, and water quality in rivers deteriorated because of poor sewage systems; consequently, Kawagoe City abolished the ordinance in October 2011. Therefore, it is important to pay attention to the level of development pressure and the permitted development regulated by ordinances because its level and contents might encourage sprawl in UCAs.
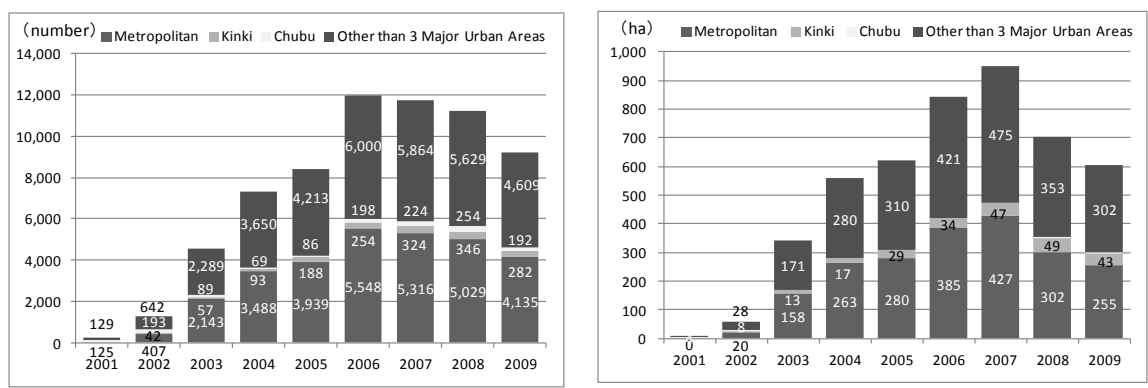

Figure 3. Permitted Development in Urban Area by Development Permission Ordinances (Left: Number of Developments, Right: Area)

Source: Added and revised by the authors based on Reference (Kobayashi, 2003)

\section{ENACTMENT BACKGROUND AND OPERATIONAL CONDITIONS OF VOLUNTARY ORDINANCES FOR LAND USE CONTROL}

\subsection{Enactment Background and Roles of Voluntary Ordinances for Land Use Control}

Although the delegation ordinances in the previous section were intended to materialize the City Planning Law within its defined scopes and subjects, real-world town planning must address the needs of diverse stakeholders as well as address diverse issues concerning cross-sectional fields. When such needs and issues exceed the scope and subject of the Law, delegation ordinances reveal their limitations. Therefore, comprehensive voluntary ordinances have been enacted on the basis of originality and ingenuity of local governments.

The enactment of voluntary ordinances in urban planning started in the $60 \mathrm{~s}$ as a complement to the development permission criteria for housing development. In the $70 \mathrm{~s}$, ordinances were developed to protect the living environment and environmental quality against medium-and high-rise buildings. In the $80 \mathrm{~s}$, ordinances were intended to enhance landscapes, including the preservation and protection of historic sites, and to develop public participation by the establishment of the District Planning system. In the 90s, ordinances responded to resort development in areas that relaxed regulations by related laws (Referred to References(Kobayashi, 1999; Kawakami, et al,2010; Kobayashi, 2003; Uchida, 2010). After 2000, because of the expansion of the ordinance enactment rights in accordance with the Omnibus Decentralization Law, comprehensive voluntary ordinances, including delegation and related ordinances, have been enacted. Additionally, diverse ordinances have been enacted, such as penalty 
regulations to ensure its effectiveness and clarification of the roles and responsibilities of citizens, administrations, and business owners.

Next, focusing on voluntary ordinances for land use control, ordinances originating from the "Guideline for Regulating Housing Development" and introduced as a supplement for the Development Permission System, were enacted to improve housing standards, meet the increasing demand for housing, and relieve increasing costs for providing infrastructure. Originally, the administrative guidance based on this Guideline had no legal grounds. However, since consultation with a public facility administrator was necessary for the developer to obtain development permission, the Guideline was actually used as a permit requirement. Thus, the Guideline had virtual legal force. Later, since the Guideline could be set down within administrative discretion and was easy to adopt, its application expanded throughout the country. However, the Administrative Procedures Act of 1993 required that the Guideline must convert to an ordinance to make its regulations and responsibilities clear. In addition, in 1995, "Instruction on Re-Evaluating the Guideline for Regulation of Development of Housing," which was a notice by the former Ministry of Construction, demanded that the legal system be followed, excessive guidance be corrected, and fairness and transparency be ensured. Thus, the Guidelines were gradually incorporated into ordinances in each local government.

Since development outside the legal planning system, such as nonbuilding development and small-scale development, does not require any development permission, such development cannot be controlled by the City Planning Law. Therefore, in targeting such development, some ordinances were established to provide a mechanism for shifting such developments into a class that suits a regional situation through prior consultation and coordination. In addition, ordinances that define a mechanism for public participation by establishing District Planning, which incorporates the enhanced intention of residents toward urban environment, have increased. In recent years, comprehensive ordinances have increased to systematize related ordinances.

\subsection{Actual Situation of Land Use Control through Voluntary Ordinances for Land Use Management}

According to the designation status of 76 voluntary ordinances for land use management, which were surveyed using a questionnaire (Figure 4), between 1981 and 1999 - a period before the enactment of the Omnibus Decentralization Law - the number of designations was 13. Between 2000 and 2011 after its enactment, the number increased about five times to 63 . Similar to the Development Permission Ordinances, the number of enacted ordinances is highest in the Kanto region where there are high pressures for development; the number in the Kanto region accounts for half the total. Among local governments outside the three metropolitan urban areas, ordinances have been enacted in diverse local governments regardless of size, including large-scale local governments - such as Sendai City, Hamamatsu City, and Kanazawa City-and small-scale local governments - such as Hikawa Town in Kumamoto Prefecture. 


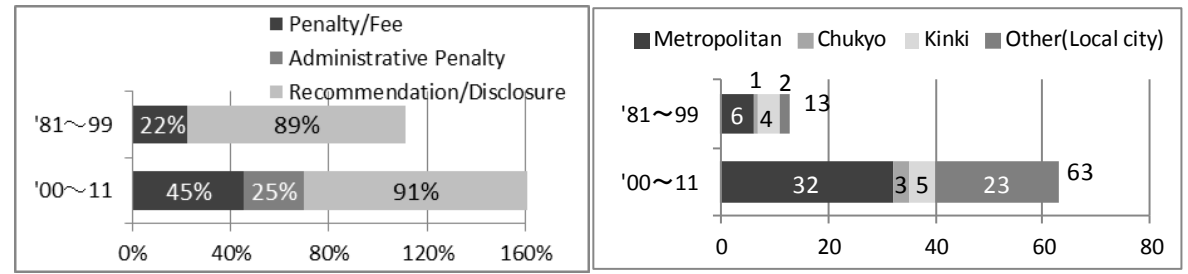

Figure 4. Enactment Area of Ordinances Figure 5. Regulations relating penalties in Ordinances

According to the number of applications and approvals/permits concerning prior consultation in accordance with ordinances (Table 3), local governments with less than 10 applications per year account for $41 \%(25$ local governments), local governments with 50-100 applications account for $26 \%$ (16 local governments), and those with more than 100 applications account for $8 \%$ (five local governments). Thus, there are differences in scope and content covered by the ordinances. In about half of local governments, one or two applications per year were withdrawn by developers after prior consultations. Approximately $10 \%$ of local governments made decisions not to approve or permit in order to reject developments that did not suit their regions. It is assumed that, as indicated in Figure 5, traditional ordinances enly had only weak powers, such as admonishment and public notice against developers who did not follow guidance, but by expanding ordinance enactment rights, enforceable ordinances have been increasing in recent years; these ordinances include regulations, such as administrative directions and penalties, when developers are in violation.

Table 3. Average Number of Applications and Their Results Annually

The number of the answer local governments(\%)

\begin{tabular}{|c|rr|rr|rr|rr|}
\hline & \multicolumn{2}{|c|}{ Application } & \multicolumn{2}{|c|}{ Authorization } & \multicolumn{2}{c|}{ Withdrawn } & \multicolumn{2}{c|}{ Not Authorized } \\
\hline 0 per year & 4 & $7 \%$ & 5 & $8 \%$ & 26 & $43 \%$ & 53 & $87 \%$ \\
\hline 1,2 per year & 7 & $11 \%$ & 7 & $11 \%$ & 29 & $48 \%$ & 8 & $13 \%$ \\
\hline 2 - 10 per year & 14 & $23 \%$ & 15 & $25 \%$ & 4 & $7 \%$ & 0 & $0 \%$ \\
\hline 10 - 20 per year & 4 & $7 \%$ & 5 & $8 \%$ & 2 & $3 \%$ & 0 & $0 \%$ \\
\hline 20 - 50 per year & 11 & $18 \%$ & 9 & $15 \%$ & 0 & $0 \%$ & 0 & $0 \%$ \\
\hline 50 - 100 per year & 16 & $26 \%$ & 15 & $25 \%$ & 0 & $0 \%$ & 0 & $0 \%$ \\
\hline 100 per year or more & 5 & $8 \%$ & 5 & $8 \%$ & 0 & $0 \%$ & 0 & $0 \%$ \\
\hline Total & 61 & $100 \%$ & 61 & $100 \%$ & 61 & $100 \%$ & 61 & $100 \%$ \\
\hline
\end{tabular}

As to the effects of ordinances (Figure 6), more than $50 \%$ of local governments cite "enforcement of regulations appropriately and guide of developments of non-subjected to laws effectively," recognizing that the ordinances not only supplement laws but also regulate and guide development that is suitable to a regional situation. In addition, there were various opinions, such as by establishing a system of public participation, residents' awareness toward urban environment will increase and policies and their reasoning to urban planning described in the Master Plan will become clear.

However, some respondents raised concerns about the ordinances (Figure 7); for example, procedures from application to approval are prolonged, and administrative workloads are increased not only for applicants but also for local government officials. Furthermore, development not subject to ordinances could become an obstacle to integrated land use control. Therefore, it is necessary to clarify urban planning goals through public participation, evaluate municipal and applicant responsibilities, and 
clearly understand that developments should be regulated and guided with flexibility. Furthermore, some opinions show that public participation mechanisms, although prepared, have not been implemented. Therefore, it is important to incorporate financial support for public participation activities as well as providing professional technical support.

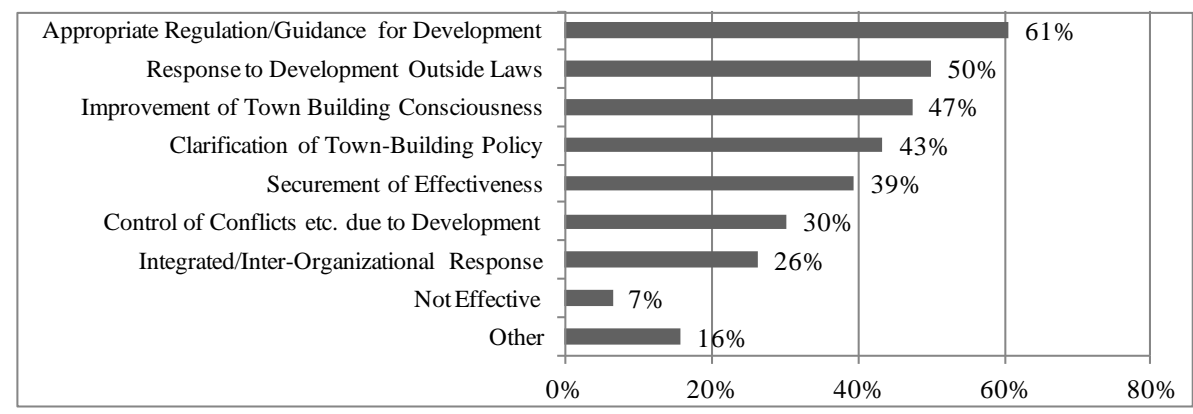

Figure 6. Effects of Ordinances

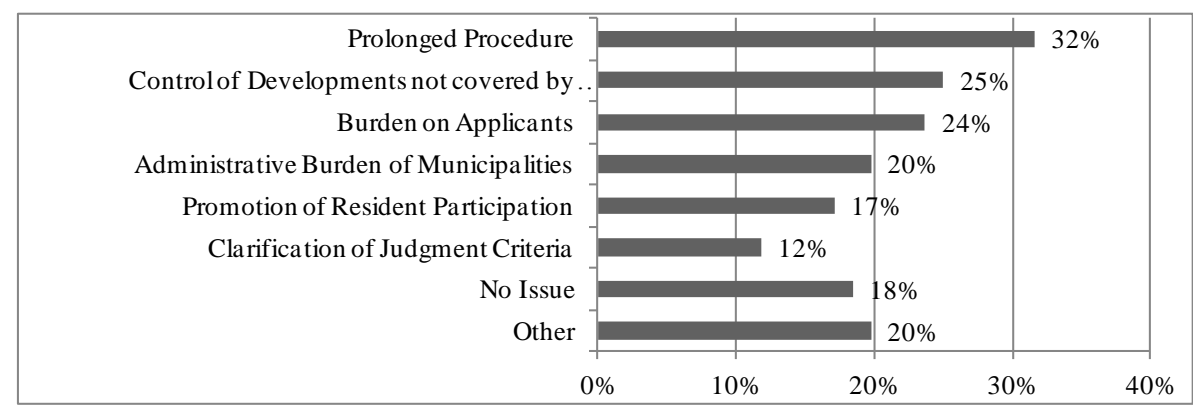

Figure 7. Issues of Ordinances

\section{EFFECTS AND PLANNING ISSUES OF LAND USE CONTROL BY LOCAL GOVERNMENT ORDINANCES}

The findings of this study on the effects of suburban land use control by local government ordinances and planning issues are summarized as follows.

(1) Effects and issues of land use control by local government ordinances

Since traditional urban planning in the growth/expansion society was required to respond to rapid urbanization, centralized land use regulations with uniform, fair, and minimum criteria were mainly adopted through the Area Division and Development Permission System. However, that traditional system was limited in its ability to respond to more recent changes in society, such as progress decreases in population and diverse local issues.

The legal reform in 2000 promoted decentralization of urban planning powers, and enabled local governments to enact ordinances, including specific regulations that started well-planned land use control in their suburban areas. However, in practice, Development Permission Ordinances, which are typical delegation ordinances for controlling suburban land use, have been used to ease existing regulations in a manner that is consistent with a growth/expansion-oriented society. Such usage is predominant in the Kanto region, which is experiencing high development pressure. A wellplanned system design and operation are needed. Therefore, as pointed out 
in the existing studies, prefecture government should make the adjustment over a wide area taking account of the intention of the relating municipality.

Voluntary ordinances have the benefit of not only supplementing laws but also guiding development to suit a regional situation, provided there is public participation and prior consultation. However, a more detailed procedure will result in more work to be done by local governments and residents. Then, a balance must be found. In addition, although mechanisms for public participation have been provided, actual activities have not always been implemented. Thus it is necessary to provide financial and technical support for implementation.

(2) Future Land Use Control by Local Government Ordinances

In traditional urban planning, suburban areas were essentially considered to be controlled by development regulations that guided development into urban areas, such as UPAs. However, in today's society where population has been decreasing and communities in rural settlements are increasingly facing difficulties in sustaining, it is thought that local government ordinances can be used to guide development activities into a hub area, such as an existing settlement. In such an approach, it is essential to formulate future planning that considers land use, industries, transportation, and welfare. It is also important to develop an appropriate planning system that suits each local situation. For example, planning must address not only land use systems, such as Development Permission Ordinances and voluntary ordinances, but also cross-sectional issues that promote reorganized living environments, which could be operated in an integrated manner under local government ordinances. Such cross-sectional measures may include prioritizing the maintenance and management of infrastructure, housing policies using "Outstanding Rural Housing System," transportation policies, such as community bus operation, and welfare policies, such as community development through drafting related plans.

\section{REFERENCES}

Akita, N., Koizumi, H. and Okata, J. (2003). "A study on the development control through the negotiation procedure-Case study on the method of the "request of beauty" by Manazuru town's machizukuri ordinance, Journal of the City Planning Institute of Japan, 38-3, 199204.

Akita, N., Yasutani, S. and Okata, J. (2001). "The Effect of a Machizukuri Ordinance for Growth Management-Case Study on the Machizukuri Ordinance of Hotaka Town, Nagano Prefecture", Journal of the City Planning Institute of Japan, 36, 1-6.

Asano, J. and Fujiwara, I. (2010). "A Study on Effects and Problems of Municipalities' Ordinance about Development Permission in Local Cities-Case Study Mainly Focused on Municipalities' Ordinance about Article 34-11 of City Planning Law," in: Journal of the City Planning Institute of Japan, 45-3, 685-691.

Fujii, S., Koyama, Y. and Ohsawa, Y. (2009). "A Study on Classification of Specific Usage Limitation Area through Analysis of Designated Areas across the Country", in: Journal of the City Planning Institute of Japan, 44-3,265-270.

Kakiuchi, T., Ebiura, M. and Nanba, K. (2010). "Operation of Development Permission Ordinance in Urbanization Control Area-A Case Study of the "Special Designated System" in Ono City, Hyogo Prefecture", in: Journal of the City Planning Institute of Japan, 45-3, 739-744.

Kawakami, M., Urayama, M., Iida, N., and Land Use Research Group. (2010). Land Use Plan for Population Decrease Era-Sustainability of Suburban Areas, Gakugei Publisher Ltd., Kyoto.

Kobayashi, S. ed. (1999). Town Planning Ordinances of Decentralization Era, Gakugei Publisher Ltd., Kyoto. 
Kobayashi, S., ed. (2003). Comprehensive Town Planning by Ordinances, Gakugei Publishing, Tokyo.

Mizuguchi, T. (1997). Land Use Plan and Town Planning-From Regulation/Guidance to Plan Consultation, Gakugei Publisher Ltd., Kyoto.

Nozawa, C. and Hori, H. (2008). "A Study on the Residential land development Control through Machidukuri Ordinance as Local rules-Case Study on Machizukuri Ordinance of Kokubunji City", in: Journal of the City Planning Institute of Japan, 43-3, 373-378.

Ohkawa, H., Matsukawa, T. Nakade, B. and Higuchi, S. (2009). "Study on the Condition and Factor of Operation of Development Permission Ordinance-Focusing on the Requirement for the Designation of 3411 Ordinance and the Analysis of the Designated Area", in: Journal of the City Planning Institute of Japan, 44-3, 661-666.

Rai, A., Marushige, Y. (2006). "Study on suburban land use control in Germany, France and the Netherlands - Towards land use control in depopulating Japan -", Policy Research for Land Infrastructure and Transport, 67.

Tadokoro, A. and Kato, H. (2011). "A Study on the Residential Land Development Control and Development Standards according to Regional Characteristics through Development Ordinances-Cases Study on Planning Ordinances of the Kamakura City and Oiso Town", in: Journal of the City Planning Institute of Japan, 46-3,553-558.

Tsukamoto, T. and Wada, O. (2005). "Applying the Amended City Planning Act in Local Central Cities-Considering the Land Use Control in Urbanization Control Area", in: Journal of the City Planning Institute of Japan, 40-3, 403-408.

Ubaura, M., Morita M.and Baba., M. (2008). "Study on urban maintenance from the widearea perspective in the decentralization society- Mainly on wide area adjustment of Germany, England and the Netherlands -", Policy Research for Land Infrastructure and Transport, 81 .

Uchida, M. (2010). Actual Situation and Theory of Town Planning Ordinances-From Supplement of City Planning Law to Tool for Autonomy, Dai-Ichi Hohki Ltd., Tokyo.

Uchiumi, M. and Kobayashi, S. (1998). "A Study on the Trend of Development Ordinance toward Generalization-The Compound Pattern and the System Pattern", in: Journal of the City Planning Institute of Japan, 33, 541-546. 